\title{
Paleoecology of Inoceramus amakusensis Nagao et Matsumoto, 1940 (Bivalvia) in a Late Cretaceous shallow clastic sea: the Himenoura Group, Kyushu, Japan
}

\author{
Taro Kumagae ${ }^{\mathrm{a}, *}$, Haruyoshi Maeda ${ }^{\mathrm{a}}$, Toshifumi Komatsu ${ }^{\mathrm{b}}$ \\ ${ }^{a}$ Division of Earth and Planetary Science, Graduate School of Science, Kyoto University, Kitashirakawa Oiwake-cho, Sakyo-ku, Kyoto 606-8502, Japan \\ ${ }^{b}$ Graduate School of Science and Technology, Kumamoto University, Kurokami, Kumamoto 860-8555, Japan
}

\begin{abstract}
The taphonomic features and paleoecology of this species were investigated focused on vertically embedded individuals of articulated Inoceramus amakusensis Nagao et Matsumoto. In the Hinoshima Formation, Himenoura Group of Kyushu, Japan, this Santonian (Late Cretaceous) inoceramid bivalve characteristically occurs in incised-valley fill siliciclastic marine deposits. Modes of I. amakusensis occurrence and preservation, from in situ (= occurrence in life position) to allochthonous shell fragments, are strongly affected by its paleoecology and depositional environments. Several I. amakusensis (up to $25 \mathrm{~cm}$ in shell height) were recovered from bioturbated sandstones associated with storm-influenced deposits. Their commissural planes are almost perpendicular to the bedding plane, with the anterior face oriented downward and the posteroventral portion extending upward. Furthermore, I. amakusensis is morphologically comparable to endobyssate mytilid bivalves today. These results suggest that this Cretaceous species was an orthothetic sand sticker at least during mid-ontogeny that preferentially inhabited a well-oxygenated, nearshore seafloor. I. amakusensis was distributed in various depositional environments and has been regarded as a recliner in offshore muddy substrate. However, the present discovery suggests that it was also well adapted, with an upright life position, to high-energy shallow clastic environments characterized by high sediment supply.
\end{abstract}

Keywords: Himenoura Group, Inoceramus amakusensis, Paleoecology, Santonian, Upper Cretaceous, Taphonomy

\section{Introduction}

Inoceramids, an extinct group of pteriomorphian bivalves, had a cosmopolitan distribution in Mesozoic marine environments (Noda and Matsumoto, 1976; Dhondt, 1992; Voigt, 1995; Harries and Crampton, 1998). They first appeared in the Early Permian, flourished during the Cretaceous Period, and became extinct in the mid-Maastrichtian, about 2 Ma before the Cretaceous-Paleogene (K-Pg) boundary (Waterhouse, 1970; Ward et al., 1991; MacLeod, 1994; Keller, 2001). On the basis of its variable shell morphology, which changed substantially over relatively short intervals in the fossil record, numerous inoceramid species have been established (Woods, 1912; Cox, 1969). Because they exhibit a widespread biogeographic distribution and short species longevity, their role as biostratigraphic index fossils for the correlation of Mesozoic marine strata, particularly during the Late Cretaceous, is well established (Harries and Crampton, 1998). Accordingly, systematic, phylogenetic, and biostratigraphic studies have been emphasized in inoceramid paleontology for centuries (e.g., Sowerby, 1814, 1822; Woods, 1912; Nagao and Matsumoto, 1939, 1940; Noda, 1975; Dhondt, 1983; Niebuhr et al., 1999; Yazykova, 2002; Walaszczyk, 2004; Walaszczyk and Cobban, 2007).

The predominance of inoceramids in several marine benthic

\footnotetext{
*corresponding author

Email address: kumagae-t@kueps.kyoto-u.ac.jp (Taro Kumagae)
}

fossil assemblages is well known, especially those from the Upper Cretaceous Series in the Western Interior and the Gulf Coast of North America (Hattin, 1982; Alencáster and Omaña, 2006; Kauffman et al., 2007), South Atlantic (Hessel, 1988), Europe (Walaszczyk, 2004; Wilmsen, 2008), and circum-Pacific regions (Haggart, 1984; Elder and Box, 1992; Yazykova, 2002; Kumagae and Komatsu, 2004; Komatsu et al., 2008; Kumagae and Misaki, 2008; Yamaguchi et al., 2008).

Despite their significance as a virtually ubiquitous component of Cretaceous benthic communities, comparatively little work has been devoted to reconstructing inoceramid paleoecology (e.g., Seitz, 1962; Kauffman, 1967; Carter, 1972; Frey, 1972; Stanley, 1972; Tanabe, 1973, 1983; Hattin, 1982; Hessel, 1988; Dhondt and Dieni, 1990, 1995; Hayakawa, 1990; Hayakawa et al., 1994; Stewart, 1990; MacLeod and Hoppe, 1992; Toshimitsu et al., 1992; Harries, 1993; Knight and Morris, 1996; Crame and Luther, 1997; Ozanne and Harries, 2002; Tanoue, 2003; Kauffman et al., 2007; Kumagae and Misaki, 2008). Therefore, biological aspects such as their life habitat, life position, and mode of life have hitherto been inadequately understood.

The Himenoura Group, a thick clastic sequence developed in shallow-marine to slope and pelagic environments (the term 'shallow-marine' is used for the depositional environments affected by waves: Walker \& Plint, 1992), is favorable for observing the modes of inoceramid occurrence and preservation (e.g., Yehara, 1922; Nagao, 1922, 1930; Nagao and Matsumoto, 
1940; Ueda, 1962; Matsumoto and Ueda, 1962). In particular, Inoceramus amakusensis Nagao et Matsumoto is common in the Hinoshima Formation, the lower part of the Himenoura Group. This species is one of the index taxa for the Santonian (Upper Cretaceous) in northeastern Eurasia (Japan, Far Eastern Russia)(Tashiro et al., 1986; Toshimitsu, 1988; Toshimitsu et al., 1995, 2007; Lamolda and Hancock, 1996; Yazykova, 2002), and it has been presumed to be an offshore mud recliner without any detailed investigation. In fact, its paleoecological aspects such as life habitat and life position have remained unknown.

Detailed field observations were made on Inoceramus amakusensis on Hinoshima and Kugushima islands, which are situated in the midwestern part of Kyushu, southwestern Japan (Fig. 1). To reconstruct the species' paleoecology, the depositional environments of the lowermost part of the Hinoshima Formation and various different modes of I. amakusensis occurrence and preservation are described. In particular, we focused on unusual in situ (= in life position) materials which provide a very important key to elucidate the paleoecology of extinct bivalves, as with inoceramids (Fürsich, 1980; Kondo, 1998).

\section{Geologic and stratigraphic framework}

The Himenoura Basin is a fault-controlled, forearc basin affected by the movement of the Median Tectonic Line (Tashiro et al., 1980; Sakai and Okada, 1997; Toyohara and Matsuo, 2000). The Upper Cretaceous is represented by the Himenoura Group (Nagao, 1922), consisting of non-marine to shallowmarine siliciclastic deposits distributed mainly in the eastern area of the Amakusa-Kamishima Island and its adjacent islands as well as the Uto Peninsula of Kumamoto Prefecture, Kyushu, southwestern Japan (Fig. 1). The Himenoura Group consists, in ascending order, of the Hinoshima and Amura formations (Tashiro and Noda, 1973; Tashiro et al., 1986) and yields abundant molluscan fossils such as ammonoids, bivalves, and gastropods (Yabe, 1900, 1902; Yehara, 1921, 1922, 1923; Nagao, 1930, 1932; Nagao and Matsumoto, 1939, 1940; Ueda and Furukawa, 1960; Matsumoto and Ueda, 1962; Ueda, 1962; Tashiro, 1976; Noda, 1983; Sato et al., 2005; Komatsu et al., 2008, 2009). On Amakusa-Kamishima Island, this Upper Cretaceous deposit unconformably overlies the basement rocks consisting of the Higo metamorphic rocks and associated granitic rocks, which are the western extension of the Higo Belt (Nagakawa et al., 1997; Toyohara and Matsuo, 2000), and is unconformably overlain by the Paleogene Akasaki Formation, Miroku Group (Nagao, 1922; Ueda, 1962; Fujino, 2003).

The present study mainly investigated the lowermost portion of the Hinoshima Formation, which is distributed on the Hinoshima and Kugushima islands, southeast of the AmakusaKamishima Island (Fig. 1). The formation in the study area reaches a thickness of more than $270 \mathrm{~m}$, strikes generally NESW, and dips at $40-70^{\circ}$ to the north (Fig. 2). Abundant fossil bivalves, a few ammonoids, and echinoids are found in shallowmarine conglomerates, sandstones, and mudstones at several localities (Figs. 3 and 4).
Two inoceramid species are used to determine the age of the Hinoshima Formation. Inoceramus amakusensis, from the lowermost part of the formation (Locs. K2001-2010, K1001-1006, H4001-4003: Figs. 3 and 4), indicates early Santonian, and $I$. higoensis Noda, from the lower portion of the formation (Locs. K2011-2019, 2021, 2024, 2025: Figs. 3 and 4), suggests late Santonian (Matsumoto, 1959; Noda, 1983; Toshimitsu et al., 1995).

Sedimentological studies of the Himenoura Group, mainly of the Hinoshima Formation, have been conducted by several geologists, who reconstructed the depositional facies development of the formation. They interpreted it as a deepeningupward succession from coarse clastic nearshore environments to turbiditic slope (Tashiro et al., 1986; Fujino, 2003; Komatsu et al., 2008). The present study basically follows Komatsu et al. (2008) in the interpretations of the depositional environments.

Komatsu et al. (2008), on the basis of depositional facies analysis, discussed in detail the depositional environments and history of the Hinoshima Formation. They recognized nine depositional facies composing four facies associations interpreted as fluvial environments, bay-head delta, central embayment, and submarine slope, and concluded that the strata represents an incised-valley fill with transgressive succession from a narrow estuary via wave-influenced marine embayment to a submarine slope environment. In particular, the lower portion of the Hinoshima Formation, which crops out in the study area, corresponds to the bay-head delta system filling the estuary and embayment. This depositional system is dominated by three shallow-marine depositional environments: distributary channel-fill and sand bar deposits in the river mouth of the delta topsets and foresets, a wave- and storm-influenced coastal sea lying between fair-weather wave base (FWWB) and storm wave base (SWB) in the distal delta foreset and marginal bay, and a marine central embayment (enclosed shallow sea) partly related to prodelta deposits (Komatsu et al., 2008).

\section{Sedimentological descriptions of inoceramid-bearing strata}

We take particular note of the sedimentary features (lithology, grain size, sedimentary structures, and fossils) of the Santonian lowermost portion of the Hinoshima Formation, indexed by the occurrence of Inoceramus amakusensis. Shell remains of I. amakusensis are distributed mainly within marine siliciclastics of incised-valley fill systems (Komatsu et al., 2008), which consist of three depositional facies: 1) cross-stratified gravelly sandstone (river mouths of bay-head delta foresets), 2) hummocky and low-angle cross-stratified sandstone (storminfluenced shallow sea), and 3) bioturbated sandy mudstone (marine embayment). These depositional facies respectively correspond to Facies 2a, 2b, and 3 recognized by Komatsu et al. (2008). The sedimentological terminology of Walker and Plint (1992), Cheel and Leckie (1993), and Johnson and Baldwin (1996) is followed. 


\subsection{Cross-stratified gravelly sandstone}

The basal portion of the Hinoshima Formation consists predominantly of medium- to very coarse-grained gravelly sandstone that overlies basement rocks and fluvial deposits (Fig. 4). This depositional facies frequently contains shell fragments of Inoceramus amakusensis, which are easily recognized by their prismatic structure visible in cross-section (Fig. 5B). In most cases, this gravelly sandstone exhibits trough and planar cross-stratification (Fig. 5A) and forms fining-upward units (2.5-7 $\mathrm{m}$ thick) beginning at a concave-up erosional basal surface. The base of the units consists of matrix-supported granule to boulder conglomerates $(0.2-1 \mathrm{~m}$ thick) containing subangular to well-rounded gravels, coaly woods, and abundant fossil bivalves, such as disarticulated Glycymeris amakusensis Nagao and shell debris from I. amakusensis, Crassostrea sp., and Spondylus sp. This conglomerate gradually grades upward into the main part of the unit, composed of mediumto coarse-grained sandstone. It is characterized by trough and planar cross-stratification, in which fragments of I. amakusensis and Crassostrea sp. distributed along foresets with granules of metamorphic and granitic rocks derived from the basement rocks are commonly observed at localities between Locs. K2001 and K2005. In this main part, lenticularly bedded, gravelly channel-fill sandstones and bivalve shell concentrations (up to $15 \mathrm{~cm}$ thick) and sheet conglomerates (3-15 cm thick) are occasionally intercalated. These cross-stratified gravelly sandstone beds gradually change upward into the finer-grained sandstone described below.

\subsection{Hummocky and low-angle cross-stratified sandstone}

Fine- to coarse-grained sandstone beds characterized by lowangle and hummocky cross-stratification (HCS), without associated mudstone beds, crop out at Locs. K2006, H4001, and H4002 (Figs. 4 and 5C, D). The HCS and low-angle crossstratified strata (0.5-4 m thick) are mainly composed of fine- to medium-grained, well-sorted sandstones with erosional bases (first-order surface: Cheel \& Leckie, 1993). The basal part (10-30 cm thick) of the beds generally consists of mediumto coarse-grained, poorly sorted sandstones with sporadic angular to rounded pebbles, rip-up mud clasts, plant remains, as well as disarticulated and fragmentary shells of Glycymeris amakusensis, Inoceramus amakusensis, and Crassostrea sp. The HCS and low-angle cross-stratified sandstones are overlain by bioturbated fine- to medium-grained sandstones $(0.2-1.5 \mathrm{~m}$ thick), which yield scattered bivalves (G. amakusensis and $I$. amakusensis) and nearly horizontal trace fossil Macaronichnus isp. (Fig. 5F).

At Loc. K4002, the gravelly sandstone bed including the fragmentary shells of Inoceramus amakusensis is overlain by the present depositional facies (5.5-6.5 $\mathrm{m}$ thick) with an erosive contact (Fig. 7). In the basal $20-45 \mathrm{~cm}$ interval above the erosional surface, characterized by low-angle cross-stratification, subangular to rounded gravels up to cobbles in size and disarticulated valves of Glycymeris amakusensis accumulated together. Fine-grained well-sorted, bioturbated sandstones overlie the lowermost part. Articulated valves of four individuals of I. amakusensis and clustered G. amakusensis (Fig. 5G) are found in this bioturbated sandstone, which is overlain by amalgamated HCS sandstones at least $3 \mathrm{~m}$ thick (Fig. 5C).

\subsection{Bioturbated sandy mudstone}

Bioturbated, dark-gray, sandy mudstone (20-40 m thick) overlies the bioturbated sandstone described above. This poorly sorted mudstone shows no obvious depositional structures because of homogenization by intense bioturbation and is occasionally intercalated with very fine- to fine-grained sandstone sheets $(5-10 \mathrm{~cm}$ thick) characterized by fine parallel lamination. Some marine invertebrate fossils and abundant plant remains are found in this depositional facies, particularly in the disk-shaped, calcareous concretions. Most of the fossil bivalves are disarticulated or fragmented (Glycymeris amakusensis, Inoceramus amakusensis, Acila hokkaidoensis Nagao, and Spondylus sp.), although some individuals of G. amakusensis occur in an articulated or butterfly position (Loc. K1002). Some fossils of stenohaline animals, such as ammonoids, echinoids, and solitary corals, also occur (Fig. 4).

\section{Modes of occurrence and preservation of Inoceramus amakusensis}

Inoceramus amakusensis is large (up to $60 \mathrm{~cm}$ in shell height) and thin-shelled $(<0.5 \mathrm{~cm})$ for the family and is characterized by being equivalved, with low convexity, irregularly spaced rugae, and large posterior wings (Fig. 6). Within shallowmarine siliciclastic deposits in the study area, I. amakusensis, which is associated with other molluscan fossils such as bivalves and ammonoids, displays various taphonomic features (Fig. 4). These are strongly controlled by the depositional environment, as well as by the paleoecology and the nature of the shell structures of the present species. The inoceramid shell, consists of an inner nacreous layer (aragonite), followed by a prismatic layer (calcite), and an outer periostracum (organic coating) (Harries et al., 1996). When the organic framework sheathing the prismatic crystals decays away, the inoceramid shell is supposedly prone to fragmentation along the boundaries between each prismatic crystal. On the basis of detailed observations of the taphonomic features of I. amakusensis in the field and laboratory, the modes of inoceramid occurrence and preservation are subdivided into three categories (Types 1-3), as described below.

\subsection{Type 1: Articulated valves}

Description. All the articulated specimens of Inoceramus amakusensis in this type are embedded vertically into to substrate. At Loc. H4002, cross-sections through articulated valves of I. amakusensis are sporadically found in the bioturbated, fine-grained sandstone associated with HCS (Fig. 8). Their commissural planes are oriented almost perpendicular to the bedding plane and strike $\mathrm{N} 60-80^{\circ} \mathrm{W}$, with umbo-down and the crushed posterior part extended upward (Figs. 7 and 8).

The stratigraphic distribution of Type 1 is unique to the storm-influenced, shallow-marine sandstones, where four individuals show sporadic distribution in a 1.5 -m-thick interval at 
Loc. H4002 (Figs. 4 and 5C). They occur together with autochthonous individuals of articulated Glycymeris amakusensis, which occur in clusters in the same locality (Fig. 5G). Disarticulated valves (Type 2) and fragmentary shells (Type 3) of $I$. amakusensis are also found in the same horizon.

In this case, only part of the disk of Inoceramus amakusensis is preserved, whereas the concentric ribs on the shell surface exhibit no signs of abrasion. As a result of post-burial processes, the shell in the umbonal area is dissolved away, and the posterior area including the posterior wing is crushed (Fig. 8). The original shell size of Type 1 individuals is estimated to be no less than $25 \mathrm{~cm}$ in height. This is the average size for $I$. amakusensis in comparison with other specimens described in previous studies (Nagao and Matsumoto, 1940; Matsumoto and Ueda, 1962; Noda and Matsumoto, 1976; Noda et al., 1995).

Interpretation. Cretaceous inoceramids essentially have no interlocking teeth (Cox, 1969; Harries and Crampton, 1998; Knight and Morris, 2009). Accordingly, when the soft tissues decay away, given the weak, multivincular ligament, the two valves are prone to disarticulation. Hence, the preservation of articulated valves of fossil inoceramids in strata indicates that they were buried in their original habitat without any postmortem transport; that is, autochthonous preservation occurred. Type 1 indicates that $I$. amakusensis assuredly inhabited storminfluenced, shallow-marine environments of sandy substrate, as Glycymeris amakusensis did (Fig. 5G).

Their unstable vertical orientation, with the umbonal region oriented downwards and the posteroventral area raised, is comparable to that of epibyssate or endobyssate mytilid bivalves of the present (in Stanley, 1970, 1972) and epifaunal edgewise recliners or semi-infaunal mud (sand) stickers (in Seilacher, 1984). The modes of occurrence of byssally attached, semiinfaunal pteriomorphians in a vertical position are observed in the Jurassic (Fürsich, 1980). Considering the shell size of Type 1 specimens ( $25 \mathrm{~cm}$ in height), the possibility that articulated shells were oriented by a post-mortem disturbance such as bioturbation or load deformation is extremely improbable. Thus, the shell orientation demonstrated by Type 1 individuals is interpreted as an original life position of Inoceramus amakusensis, and Type 1 represents in situ preservation of this species (Fig. 9).

\subsection{Type 2: Disarticulated valves}

Description. On the bedding plane of bioturbated sandstone associated with HCS (Locs. K2005 and H4002) and sandy mudstones (Locs. K2010 and H4003), Inoceramus amakusensis infrequently occurs as well-preserved disarticulated valves lying parallel to the bedding plane in convex-up position. Although inoceramid valves are found in these high-energy depositional environments, they are comparatively well preserved: the umbonal area, posterior wing, ventral margin, and faint concentric lines still remain (Figs. 5H and 6). Type 2 is, therefore, distributed in the storm-influenced shallow sea and the central embayment (Figs. 4 and 5E, H). The shell size of some individuals exceeds $40 \mathrm{~cm}$ in height, and no individuals smaller than $15 \mathrm{~cm}$ in height are found (Figs. 5E and 6).
In the storm-influenced, coastal sandstones, Type 2 Inoceramus amakusensis co-occurs with autochthonous Glycymeris amakusensis and occasionally represents shell accumulations consisting of a few individuals (Fig. 5E). In addition, in the sandy mudstone of the central embayment, they are sparsely found together with G. amakusensis, Acila hokkaidoensis, ammonoids, solitary corals, and coaly plant particles. At the same time, these Type 2 individuals are associated with Type 1 and Type 3 in the storm-influenced, shallow-marine environment and with shell fragments of Type 3 in the central bay (Fig. 4).

Interpretation. Type 2 is interpreted as a para-autochthonous occurrence for the following reasons. The predominance of convex-up shells is consistent with previous studies which demonstrated that this orientation is hydrodynamically stable for a single bivalve shell in moderate- to high-energy environments (Emery, 1968; Salazar-Jiménez and Frey, 1982; Norris, 1986; Dent and Uhen, 1993; Dey, 2003). Hence, disarticulated valves in a convex-up position are attributed to the influence of waves or currents, and they could suggest reorientation. Depositional environments where the Type 2 occurrence is distributed, as described above, are surely affected by wave and storm disturbances, and therefore, reorientation is consistent with this observation.

Although Type 2 individuals are embedded within wave- and storm-influenced sandy deposits, and the shells of Inoceramus amakusensis are not very thick $(<0.5 \mathrm{~cm})$ for the overall shell size (up to $60 \mathrm{~cm}$ in height: Noda and Matsumoto, 1976), brittle marginal parts such as the umbo, posterior wing, and ventral margin still remain (Figs. 5H and 6). This suggests rapid burial and little post-mortem transport from their life habitat and supports a para-autochthonous interpretation.

\subsection{Type 3: Fragmented shells}

Description. Fragmented shells of Inoceramus amakusensis characterize the lowermost part of the Hinoshima Formation (Fig. 4). This demonstrates the worst preservational state of $I$. amakusensis. The shell debris varies in size, ranging from 0.5 to $6 \mathrm{~cm}$ in the long axis, and its shapes are also varied from prism to block. The periostracum and the nacreous layer (aragonite) are generally dissolved or abraded.

This type is widespread in the bay-head delta and marine embayment (Fig. 4). In the river mouth channel-fill gravelly deposits, fragmented shells of Inoceramus amakusensis, associated with disarticulated Glycymeris amakusensis and fragmented Crassostrea sp. and Spondylus sp., are embedded along the foresets of trough and planar cross-stratifications (Fig. 5B) and appear randomly in the lag deposits of channel infillings and lenticular shell concentrations. In addition, in the storminfluenced sandstone beds, fragments accumulated as lag deposits that cover the first-order surfaces of HCS, together with rip-up mud clasts, disarticulated G. amakusensis, and fragmentary Crassostrea sp. In the sandy mudstone of the embayment, shell debris has three different appearances: 1) scattered occurrence with disarticulated $G$. amakusensis and coaly plant debris, 2) patchy two-dimensional shell concentrations (less than $1 \mathrm{~cm}$ thick), which originated from a single individual of $I$. amakusensis without any other fossils, and 3) limited presence 
in calcareous loose concretions that contain G. amakusensis, Acila hokkaidoensis, Protexanites sp., Polyptychoceras sp., juvenile Gaudryceras sp. ( $<1 \mathrm{~cm}$ in diameter), solitary corals, and coaly plant debris (Fig. 4).

Interpretation. Type 3 indicates the dominant allochthonous occurrence. In the lowermost Hinoshima Formation, shell remains of Inoceramus amakusensis obviously act as sedimentary particles (Fig. 5B), and, therefore, were transported from their original habitats to several depositional environments (Fig. 4). Owing to the nature of inoceramid shells, however, near their habitats, where storms and waves had substantial effects, the shells of I. amakusensis nevertheless could be readily fragmented.

As a result, inoceramid shell remains are spread and accumulated in the shallow-marine bay-head delta and central embayment and co-occur with other bivalves. The genus Crassostrea has been a typical brackish-water taxa since the Late Jurassic (Komatsu et al., 2002; Komatsu, 2004); moreover, the inferred life habitat of Glycymeris amakusensis is on a wellsorted sandy shoreface to inner shelf (Kumagae and Komatsu, 2004). Shell fragments embedded in channel-fill and coarser, storm-influenced lag deposit, in particular, underwent physical destruction including abrasion by comparatively energetic flow (Driscoll and Weltin, 1973). Sato et al. (2005) and Komatsu et al. (2009) reported I. amakusensis from turbiditic sandstone beds in basin and submarine fan systems in the middle and upper parts of the Hinoshima Formation. The shells of I. amakusensis are poorly preserved as disarticulated valves and fragments on the erosional basal surfaces of turbidites. These shell remains appear to be transported from the coastal marine environments to the basin and submarine fan.

\section{Paleoecological considerations of Inoceramus amakusen- sis in a shallow clastic sea, the Himenoura Basin}

\subsection{Life habitat}

Inoceramid bivalves once inhabited widely diverse marine environments ranging from nearshore sands to offshore muds and chalks (Carter, 1972; Frey, 1972; Hattin, 1982; Harries and Crampton, 1998; Kumagae and Misaki, 2008). Moreover, some of them, potentially with chemosynthetic symbionts, might have successfully ventured into oxygen-deficient sea bottoms, which were generally uninhabitable by other benthic marine forms (MacLeod and Hoppe, 1992; Kauffman et al., 2007). While most inoceramids were definitely bottom-dwellers, a few forms could be pseudoplanktonic, attaching themselves to various floating objects such as ammonoid shells and driftwood in seawater, for part or whole of their lifetime (Jefferies and Minton, 1965; Tanabe, 1973, 1983). However, it is still controversial whether the pseudoplanktonic life habit is appropriate for inoceramids, and thus other bivalves (Harries and Crampton, 1998; Schatz, 2005).

Several Inoceramus amakusensis specimens from the lowermost Hinoshima Formation occur in situ. Such specimens cooccur with articulated Glycymeris amakusensis in bioturbated sandstones in storm-influenced environments (Figs. 5G and 7).
Kumagae and Komatsu (2004) described a dense occurrence of autochthonous $G$. amakusensis within bioturbated sandstone on top of an HCS sequence in the Himenoura Group on the Oshima Island, southwest of Amakusa-Shimojima Island (Fig. 1A) and reconstructed its life habitat as a wave- and storm-dominated sandy shoreface to inner shelf. Moreover, bioturbated sandstone beds correspond to the burrowed flat laminae $(\mathrm{Fb})$ or cross laminae $(\mathrm{Xb})$ intervals (Dott and Bourgeois, 1982) that indicate the active behavior of marine benthos under calm conditions between storms (Cheel and Leckie, 1993; Johnson and Baldwin, 1996).

Storms with breaking waves play a crucial role in introducing dissolved oxygen into seawater (Wallace and Wirick, 1992; Chanson and Cummings, 1994; Nittrouer and Wright, 1994; Chanson et al., 2006). As cluster occurrences of autochthonous Glycymeris amakusensis and a densely bioturbated lithology (Fig. 5G, F) suggest, high activity of marine benthos would be allowed under such mixed (aerobic) condition (Savrda et al., 1984) existing between FWWB and SWB within the Himenoura Basin. Consequently, Inoceramus amakusensis inhabited a well-oxygenated sandy substrate of a shallow clastic sea with no demand for chemosymbiotic adaptations.

\subsection{Life position}

Previous studies of the life positions of inoceramids have been conducted on the basis of their modes of occurrence and preservation, functional morphology, and other indirect circumstantial evidence. In most cases, fossil inoceramids used for these studies were mainly obtained from calcareous chalk or offshore mudstone (Bottjer, 1981; Jablonski and Bottjer, 1983; Kauffman et al., 2007), that is, initially soft, and potentially soupy substrates inhospitable to infaunal suspension feeders (Seibold and Berger, 1982; McCave and Jones, 1988; Egeberg and Saigal, 1991; Stow et al., 1996). Based on this, the life positions of several Upper Cretaceous inoceramid species have been inferred with iceberg or snowshoe adaptations (in Thayer, 1974, 1975): Platyceramus platinus (Logan) and Cladoceramus undulatoplicatus (Römer) were considered as snowshoe strategists for their large flattened thin-shelled valve (Frey, 1972; Hattin, 1982; Kauffman et al., 2007); Inoceramus lamarcki Parkinson and Volviceramus involutus (Sowerby) $[?=$ V. grandis (Conrad)] were considered as iceberg strategists for their bowlshaped left valve (Carter, 1972; Frey, 1972; Hattin, 1982).

A few previous reconstructions promoting an upright life position for Late Cretaceous inoceramids exist [ e.g., Dhondt and Dieni (1990, 1995) for Cladoceramus undulatoplicatus, Stewart (1990) for Platyceramus platinus, and Toshimitsu et al. (1992) for Sphenoceramus schmidti (Michael)]. The first three studies used evidence of bivalve and cirriped encrustation on the shell surface of host inoceramids, whereas the latter examined the preferred orientation of individuals. However, since all of the studies are based on equivocal data, these reconstructions of upright position are still debatable.

Here, Inoceramus amakusensis is reconstructed as semiinfaunal, and thus, it was an orthothetic sand sticker in shallowmarine environments. Above all, articulated individuals that 
exhibit vertical umbo-low and posterior-up orientation are obviously indicative of an erect life position (Figs. 8 and 9), although Seilacher (1984) interpreted this umbo-down position as a result of the pull of the byssus in response to burying alive. This is supported by Tashiro (1978) and Noda et al. (1995), who reported two bivalve species, Atreta intulaevis Tashiro and Pycnodonte amakusensis Tashiro attached on both (right and left) valves of immature individuals of I. amakusensis. It is interpreted to suggest that both discs, during early ontogeny, were located above the sediment-water interface when the inoceramid animal was alive (Toshimitsu et al., 1992).

Several accounts reinforce the reconstruction of the life position of Inoceramus amakusensis as a sand sticker. The shell is less inflated, and the anterior end of the conjoint valves forms a cuneiform edge; moreover, the cross-sectional shape of the shell reaches its greatest width nearly at the middle of the dorsoventral axis (Fig. 9). These morphological characteristics are typical of semi-infaunal modern mytilids and burrowing bivalves (Stanley, 1970, 1972). To securely settle at a sandy bottom, I. amakusensis likely required the burial of a portion of its body in the substrate. Shell valves themselves function as an anchor in the sediments (Seilacher, 1984). Furthermore, considering this species' shell size (25 cm in height), I. amakusensis potentially held its body firmly to the seafloor with a byssus as an additional anchor. Although it is assumed, but not substantiated, that this inoceramid possessed a byssus, the presence of a byssus is one of the diagnoses for the superfamily Pteriacea, in which inoceramids are classified. In addition, the presence of a byssal notch, from which byssus passing outward from the valve, was confirmed in several inoceramid species by previous studies (Seitz, 1962; Cox, 1969; Kauffman, 1969; Stanley, 1972; Harries and Crampton, 1998).

The cross-sectional shape of Inoceramus amakusensis is unlikely to contribute to the physical stabilization in an epifaunal habit (Fig. 9). If I. amakusensis was an epibyssate strategist, considering its storm-influenced life habitat and comparatively large size in the Type 1 occurrence, a secure byssus that anchors its body vertically and firmly to the seafloor or densely packed gregariousness may be required (Fürsich, 1980). However, any reliable objects to which byssal threads are attached are not found in sediments around their anterior margin, and in situ individuals of the species occur solitarily, not in clusters (Fig. 8).

The life strategy of semi-infaunal sand (mud) stickers could allow themselves to survive relatively high sedimentation rate (Seilacher, 1984, 1985) and high-energy depositional environments (Stanley, 1970, 1972). The erect life position of Inoceramus amakusensis enables it to position its posteroventral shell margin such that the gills and mantle tissue are located well above the sediment-water interface. This upright position, for this originally sessile inoceramid, is effective against rapid burial (Chinzei, 1982; Chinzei et al., 1982) and offers an advantage in a benthic suspension-feeding community in terms of tiering (Ausich and Bottjer, 1982). As such an environment is likely affected by storms and waves, a semi-infaunal life habit is potentially an effective strategy to prevent excavation from the sediment (Kauffman, 1969). Furthermore, the posterior wing of byssate bivalves functions as s stabilizing rudder (Kauffman, 1969). Also, the preferential shell orientation affected by river current or tidal flow is known in several suspension-feeding bivalves [e.g. Toshimitsu et al. (1992) for Margaritifera laevis (Haas) and Mathers (1976) for Pecten maximus (Linnaeus)]. The preferred orientation of the commissural plane of I. amakusensis may suggest that they settled on the sea bottom with their posterior wing parallel to the predominant flow direction. The paleoecology of I. amakusensis described above denotes an example of an essentially immobile inoceramid's adaptation to a shallow clastic environment with storm and wave disturbances and a high sediment supply.

\section{Conclusions}

The Santonian inoceramid bivalve Inoceramus amakusensis as found within a shallow-marine siliciclastic sequence of the Upper Cretaceous Himenoura Group represents various modes of occurrence and preservation from in situ valves to allochthonous shell debris. Taphonomic features of this species are subdivided into three categories: Type 1, characterized by articulation and vertical embedding, is only observed in storm-influenced, coastal sandstones and is interpreted as in situ preservation; Type 2, showing disarticulation and good preservation, is found in the bay-head delta foresets, storm-influenced sandstones, and central bay environments and is interpreted as para-autochthonous; and Type 3, composed of fragmentary shells, exhibits a widespread distribution throughout the lowermost part of the Hinoshima Formation and indicates typical allochthonous occurrences.

In the Himenoura Basin, Inoceramus amakusensis was an orthothetic, semi-infaunal sand sticker that preferentially inhabited an aerobic nearshore environment between fair-weather and storm wave base (SWB). The inhabited substrate of this species consists of well-sorted, fine-grained sands that accumulated in the distal area of a bay-head delta. Well-oxygenated seawater in the inoceramid habitat allowed I. amakusensis to subsist without chemosymbiosis. This inoceramid species partially buried its dorsoanterior face into the sandy bottom, and potentially, anchored itself by a byssus to affix its body in a habitat influenced by storms and waves. This vertical position is an effective strategy for preventing I. amakusensis from storm and wave disturbances and rapid burial, and offers an advantage in tiering a benthic suspension-feeding community. In the Santonian of the Yezo Group, northeast Japan, large articulated $I$. amakusensis (over $60 \mathrm{~cm}$ in height) lying on a bedding plane of bioturbated mudstone on a slope to a proximal basin plain below SWB are occasionally observed. This might suggest that this species was a recliner snowshoe strategist owing to either its large shell size at a later growth stage, an offshore soft bottom condition, or both.

Inoceramus amakusensis, possibly by changing its life habit flexibly, could have adapted to various marine environments. In any case, further studies are required to clarify its range of inhabited paleoenvironments as well as life positions. 


\section{Acknowledgments}

The authors are deeply grateful to M. Noda and the late A. V. Dhondt for valuable suggestions on the taxonomy and paleoecology of inoceramids, and to K. Chinzei, T. Ohno, H. Naruse, T. Nishimura, and A. Misaki for fruitful discussions and advices during the course of this study. We thank M. Ono, K. Nagata, K. Chikushi, and S. Sato for their assistance during fieldwork. Sincere thanks are extended to F. Toyohara, Y. Shigeta, and K. Sato for their kind cooperation, and to the librarians at the Earth \& Planetary Sciences Library, Kyoto University for help in collecting literature. Insightful revisions by P. J. Harries, and thoughtful comments by the Editor, M. B. Hart greatly improved the original manuscript. Funding for this study was provided in part by Grants-in-Aids from the Fukada Geological Institute (2007) and the Fujiwara Natural History Foundation (2008) to T. Kumagae, and the Japanese Ministry of Education, Culture, Sports, Science, and Technology (No. 21540483) to H. Maeda.

\section{References}

Alencáster, G., Omaña, L., 2006. Maastrichtian inoceramid bivalves from central Chiapas, southeastern México. Journal of Paleontology 80, 946-957.

Ausich, W.I., Bottjer, D.J., 1982. Tiering in suspension-feeding communities on soft substrata throughout the Phanerozoic. Science 216, 173-174.

Bottjer, D.J., 1981. Structure of Upper Cretaceous Chalk benthic communities, southwestern Arkansas. Palaeogeography, Palaeoclimatology, Palaeoecology 34, 225-256.

Carter, R.M., 1972. Adaptations of British Chalk Bivalvia. Journal of Paleontology 46, 325-341.

Chanson, H., Aoki, S., Hoque, A., 2006. Bubble entrainment and dispersion in plunging jet flows: Freshwater $v s$. Seawater. Journal of Coastal Research 22, 664-677.

Chanson, H., Cummings, P.D., 1994. Effects of plunging breakers on the gas contents in the ocean. Marine Technology Society Journal 28, 22-32.

Cheel, R., Leckie, D., 1993. Hummocky cross-stratification, in: Wright, V.P. (Ed.), Sedimentology Review/1. Wiley-Blackwell Science Publications, Oxford, pp. 103-122.

Chinzei, K., 1982. Morphological and structural adaptations to soft substrates in the Early Jurassic monomyarians Lithiotis and Cochlearites. Lethaia 15, 179-197.

Chinzei, K., Savazzi, E., Seilacher, A., 1982. Adaptational strategies of bivalves living as infaunal secondary soft bottom dwellers. Neues Jahrbuch für Geologie und Paläontologie Abhandlungen 164, 229-244.

Cox, L.R., 1969. Family Inoceramidae, in: Moore, R.C. (Ed.), Treatise on Invertebrate Paleontology. Part N, Mollusca 6, Bivalvia 1. The Geological Society of America, Inc. / The University of Kansas, Boulder / Lawrence, pp. N314-N321

Crame, J.A., Luther, A., 1997. The last inoceramid bivalves in Antarctica. Cretaceous Research 18, 179-795.

Dent, S.R., Uhen, M.D., 1993. Tidal reorientation and transport of Recent bivalves on a temperate tidal flat, northwestern U.S. Palaios 8, 244-249.

Dey, S., 2003. Incipient motion of bivalve shells on sand beds under flowing water. Journal of Engineering Mechanics, ASCE 129, 232-240.

Dhondt, A.V., 1983. Campanian and Maastrichtian inoceramids: A review. Zitteliana 10, 687-701.

Dhondt, A.V., 1992. Cretaceous inoceramid biogeography: A review. Palaeogeography, Palaeoclimatology, Palaeoecology 92, 217-232.

Dhondt, A.V., Dieni, I., 1990. Unusual inoceramid-spondylid association from the Cretaceous Scaglia Rossa of Passo del Broncon (Trento, northern Italy) and its palaeontological significance. Memoirs of the Institute of Geology and Mineralogy, University of Padova 42, 155-179, 3 pls.

Dhondt, A.V., Dieni, I., 1995. Synecology of an unusual Late Cretaceous inoceramid-spondylid association from northern Italy. Annali dei Musei Civici di Rovereto. Sezione, Scienze Naturali 11, 327-338.
Dott, R.H.J., Bourgeois, J., 1982. Hummocky stratification: Significance of its variable bedding sequences. Geological Society of America Bulletin 93, 663-680.

Driscoll, E.G., Weltin, T.P., 1973. Sedimentary parameters as factors in abrasive shell reduction. Palaeogeography, Palaeoclimatology, Palaeoecology 13, 275-288.

Egeberg, P.K., Saigal, G.C., 1991. North Sea chalk diagenesis: cementation of chalks and healing of fractures. Chemical Geology 92, 339-354.

Elder, W.P., Box, S.E., 1992. Late Cretaceous inoceramid bivalves of the Kuskokwim Basin, southwestern Alaska, and their implications for basin evolution. Paleontological Society Memoir 26, 1-39.

Emery, K.O., 1968. Positions of empty pelecypod valves on the continental shelf. Journal of Sedimentary Petrology 38, 1264-1269.

Frey, R.W., 1972. Paleoecology and depositional environment of Fort Hays Limestone Member, Niobrara Chalk (Upper Cretaceous), west-central Kansas. University of Kansas, Paleontological Contributions, Article 58, $1-72,15$ pls.

Fujino, S., 2003. Sedimentary facies and modes of fossil occurrence in the Upper Cretaceous Hinoshima Formation of the Himenoura Group in AmakusaKamishima Island, southwest Japan. Bulletin of the Mikasa City Museum 7, 27-37, pl. 1 (in Japanese, English abstract).

Fürsich, F.T., 1980. Preserved life positions of some Jurassic bivalves. Paläontologische Zeitschrift 54, 289-300.

Haggart, J.W., 1984. Upper Cretaceous (Santonian-Campanian) ammonite and inoceramid biostratigraphy of the Chico Formation, California. Cretaceous Research 5, 225-241.

Harries, P.J., 1993. Dynamics of survival following the Cenomanian-Turonian (Upper Cretaceous) mass extinction event. Cretaceous Research 14, 563583.

Harries, P.J., Crampton, J.S., 1998. The inoceramids. American Paleontologist 6, 2-6.

Harries, P.J., Kauffman, E.G., Crampton, J.S., etal., 1996. Lower Turonian Euramerican Inoceramidae: A morphologic, taxonomic, and biostratigraphic overview. Mitteilungen aus dem Geologisch-Paläontologischen Museum der Universität Hamburg 77, 641-671.

Hattin, D.E., 1982. Stratigraphy and depositional environment of Smoky Hill Chalk Member, Niobrara Chalk (Upper Cretaceous) of the type area, western Kansas. Kansas Geological Survey Bulletin 225, 1-108.

Hayakawa, H., 1990. Sedimentologic controland paleoenvironmental implications on shell concentrations: an example of Inoceramus uwajimensis Yehara from the Upper Cretaceous of Hokkaido, Japan. Fossils (Journal of the Palaeontological Society of Japan) 48, 1-16 (in Japanese, English abstract).

Hayakawa, H., Tashiro, M., Nishino, T., 1994. Colony of Inoceramus (Cataceramus) balticus Boehm and process of preservation. Research Reports of the Kochi University, Natural Science 43, 183-191, pl. 1-2 (in Japanese, English abstract).

Hessel, M.H.R., 1988. Lower Turonian inoceramids from Sergipe, Brazil: systematics, stratigraphy and palaeoecology. Fossils and Strata 22, 1-49.

Jablonski, D., Bottjer, D.J., 1983. Soft-bottom epifaunal suspension-feeding assemblages in the Late Cretaceous, in: Tevesz, M.J.S., McCall, P.L. (Eds.), Biotic Interactions in Recent and Fossil Benthic Communities. Plenum Press, New York, pp. 747-812.

Jefferies, R.P.S., Minton, P., 1965. The mode of life of two Jurassic species of "Posidonia". Palaeontology 8, 156-185, pl. 19.

Johnson, H.D., Baldwin, C.T., 1996. Shallow clastic seas, in: Reading, H.G. (Ed.), Sedimentary Environments: Processes, Facies and Stratigraphy. Blackwell Science, Oxford, 3rd edition. pp. 232-280.

Kauffman, E.G., 1967. Coloradoan macroinvertebrate assemblages central Western Interior United States, in: Kauffman, E.G., Kent, H.C. (Eds.), Paleoenvironments of the Cretaceous Seaway - A Symposium. May 1967, Colorado School of Mines, Golden, pp. 67-143.

Kauffman, E.G., 1969. Form, function, and evolution, in: Moore, R.C. (Ed.), Treatise on Invertebrate Paleontology. Part N, Mollusca 6, Bivalvia 1. The Geological Society of America, Inc. / The University of Kansas, Boulder / Lawrence, pp. N130-N205.

Kauffman, E.G., Harries, P.J., Meyer, C., Villamil, T., Arango, C., Jaecks, G., 2007. Paleoecology of giant inoceramidae (Platyceramus) on a Santonian (Cretaceous) seafloor in Colorado. Journal of Paleontology 81, 64-81.

Keller, G., 2001. The end-Cretaceous mass extinction in the marine realm: year 2000 assessment. Planetary and Space Science 49, 817-830. 
Knight, R.I., Morris, N.J., 1996. Inoceramid larval planktotrophy: evidence from the Gault Formation (middle and basal Upper Albian), Folkestone, Kent. Palaeontology 39, 1027-1036.

Knight, R.I., Morris, N.J., 2009. A reconsideration of the origins of the 'typical' Cretaceous inoceramid calcitic hinge plate in the light of new ultrastructural observations from some Jurassic 'inoceramids'. Palaeontology 52, 963-989.

Komatsu, T., 2004. Present states of research in the Mesozoic brackish-water bivalve assemblages in Japan: habitats of the Cretaceous bivalves in the Amakusa area, and paleoecology of the Jurassic to Cretaceous true oyster. Fossils (Journal of the Palaeontological Society of Japan) 76, 76-89 (in Japanese, English abstract).

Komatsu, T., Chinzei, K., Zakhera, M.S., Matsuoka, H., 2002. Jurassic softbottom oyster Crassostrea from Japan. Palaeontology 45, 1037-1048.

Komatsu, T., Naruse, H., Manabe, M., Tsuihiji, T., Ikegami, N., Takashima, R., 2009. Cretaceous non-marine and shallow marine facies and fossil in western Kumamoto, Kyushu, Japan. 4th International Symposium, IGCP507, Paleoclimates of the Cretaceous in Asia and their global correlation, Field Excursion Guidebook, 1-59.

Komatsu, T., Ono, M., Naruse, H., Kumagae, T., 2008. Upper Cretaceous depositional environments and bivalve assemblages of far-east Asia: the Himenoura Group, Kyushu, Japan. Cretaceous Research 29, 489-508.

Kondo, Y., 1998. Adaptive strategies of suspension-feeding, soft-bottom infaunal bivalves to physical disturbance: evidence from fossil preservation, in: Johnston, P.A., Haggart, J.W. (Eds.), Bivalves: an eon of evolution, Paleobiological Studies Honoring Norman D. Newell. University of Calgary Press, Calgary, pp. 377-392.

Kumagae, T., Komatsu, T., 2004. Depositional environments and bivalve assemblages of the Upper Cretaceous Himenoura Group, Oshima, Amakusa Islands, Kyushu, Japan. Fossils (Journal of the Palaeontological Society of Japan) 76, 63-75 (in Japanese, English abstract).

Kumagae, T., Misaki, A., 2008. Palaeoecology and modes of occurrence of Inoceramus uwajimensis (bivalvia) and depositional environments of the Upper Cretaceous (Coniacian) Upper Yezo Group. Report of the Fukada Grants-in-Aid for 2007 , 155-170 (in Japanese).

Lamolda, M.A., Hancock, J.M., 1996. The Santonian Stage and substages, in: Rawson, P.F., Dhondt, A.V., Hancock, J.M., Kennedy, W.J. (Eds.), Proceedings of the Second International Symposium on Cretaceous Stage Boundaries: Bulletin de l'Institut Royal des Sciences Naturelles de Belgique, Sciences de la Terre 66, Supplement, pp. 95-102.

MacLeod, K.G., 1994. Bioturbation, inoceramid extinction, and midMaastrichtian ecological change. Geology 22, 139-142.

MacLeod, K.G., Hoppe, K.A., 1992. Evidence that inoceramid bivalves were benthic and harbored chemosynthetic symbionts. Geology 20, 117-120.

Mathers, N. F., 1976. The effects of tidal currents on the rhithm of feeding and digestion in Pecten maximus L. Journal of experimental marine biology and ecology 24, 271-283.

Matsumoto, T., 1959. Zonation of the Upper Cretaceous in Japan. Memoirs of the Faculty of Science, Kyushu University, Series D, Geology 9, 55-93, pl. 6-11.

Matsumoto, T., Ueda, Y., 1962. Palaeontological notes. in Ueda (1962). Memoirs of the Faculty of Science, Kyushu University, Series D, Geology 12, 161-178, pl. 22-27.

McCave, I.N., Jones, K.P.N., 1988. Deposition of ungraded muds from highdensity turbidity currents. Nature 333, 250-252.

Nagakawa, K., Obata, M., Itaya, T., 1997. K-Ar ages of the Higo metamorphic belt. Journal of the Geological Society of Japan 103, 943-952 (in Japanese, English abstract).

Nagao, T., 1922. Geology of Amakusa area -preliminary report 1-. Journal of the Geological Society of Japan 29, 41-56 (in Japanese).

Nagao, T., 1930. On some Cretaceous fossils from the islands of Amakusa, Kyushu, Japan. Journal of the Faculty of Science, Hokkaido Imperial University, Series 4, Geology and Mineralogy 1, 1-25, pl. 1-3.

Nagao, T., 1932. Some Cretaceous Mollusca from Japanese Saghalien and Hokkaido (Lamellibranchiata and Gastropoda). Journal of the Faculty of Science, Hokkaido Imperial University, Series 4, Geology and Mineralogy 42, 23-50.

Nagao, T., Matsumoto, T., 1939. A monograph of the Cretaceous Inoceramus of Japan. part I. Journal of the Faculty of Science, Hokkaido Imperial University, Series 4, Geology and Mineralogy 4, 241-299, pl. 23-35.

Nagao, T., Matsumoto, T., 1940. A monograph of the Cretaceous Inoceramus of Japan. part II. Journal of the Faculty of Science, Hokkaido Imperial Uni- versity, Series 4, Geology and Mineralogy 6, 1-64, pl. 1-22.

Niebuhr, B., Baldschuhn, R., Ernst, E., Walaszczyk, I., Weiss, W., Wood, C.J., 1999. The Upper Cretaceous succession (Cenomanian-Santonian) of the Staffhorst Shaft, lower Saxony, northern Germany: Integrated biostratigraphic, lithostratigraphic and downhole geophysical log data. Acta Geologica Polonica 49, 175-213.

Nittrouer, C.A., Wright, L.D., 1994. Transport of particles across continental shelves. Reviews of Geophysics 32, 85-113.

Noda, M., 1975. Succession of inoceramus in the Upper Cretaceous of southwest Japan. Memoirs of the Faculty of Science, Kyushu University, Series D, Geology 23, 221-261, pl. 32-37.

Noda, M., 1983. Note on the so-called Inoceramus japonicus (bivalvia) from the Upper Cretaceous of Japan. Transactions and Proceedings of the Palaeontological Society of Japan, New Series 132, 191-219, pl. 41-46.

Noda, M., Matsumoto, T., 1976. Mesozoic molluscan fossils of Japan 4, Cretaceous Inoceramus 3, in: Editorial Commitee of 'Atlas of Japanese Fossils' (Ed.), Atlas of Japanese Fossils, no. 45. Tsukiji Shokan Publishing, Tokyo (in Japanese).

Noda, M., Otsuka, M., Kano, M., Toshimitsu, S., 1995. The Cretaceous inoceramids from the Mifune and Himenoura Groups in Kyushu. Special Issue of the Geological Society of Oita 2, 1-63, pl. 1-15 (in Japanese).

Norris, R.D., 1986. Taphonomic gradients in shelf fossil assemblages: Pliocene Purisima Formation, California. Palaios 1, 256-270.

Ozanne, C.R., Harries, P.J., 2002. Role of predation and parasitism in the extinction of the inoceramid bivalves: an evaluation. Lethaia 35, 1-19.

Sakai, T., Okada, H., 1997. Sedimentation and tectonics of the Cretaceous sedimentary basins of axial and Kurosegawa Tectonic Zones in Kyushu, SW Japan. Memoirs of the Geological Society of Japan 48, 7-28.

Salazar-Jiménez, A., Frey, R.W., 1982. Concavity orientations of bivalve shells in estuarine and nearshore shelf sediments, Georgia. Journal of Sedimentary Petrology 52, 565-586.

Sato, S., Kumagae, T., Nagata, K., Ono, M., Komatsu, T., 2005. Bivalve assemblages in submarine levee and overbank deposits of the Upper Cretaceous Hinoshima Formation, Himenoura Group. Bulletin of the Mikasa City Museum 9, 1-10 (in Japanese, English abstract).

Savrda, C.E., Bottjer, D.J., Gorsline, D.S., 1984. Development of a comprehensive oxygen-deficient marine biofacies model: evidence from Santa Monica, San Pedro, and Santa Barbara basins, California continental borderland. American Association of Petroleum Geologists Bulletin 68, 1179-1192.

Schatz, W., 2005. Palaeoecology of the Triassic black shale bivalve Daonellanew insights into an old controversy. Palaeogeography, Palaeoclimatology, Palaeoecology 216, 189-201.

Seibold, E., Berger, W.H., 1982. The sea floor: an introduction to marine geology. Springer-Verlag, Berlin/Heidelberg.

Seilacher, A., 1984. Constructional morphology of bivalves - evolutionary pathways in primary versus secondary soft-bottom dwellers. Palaeontology 27, 207-237.

Seilacher, A., 1985. Bivalve morphology and function, in: Broadhead, T.W. (Ed.), Mollusks: Notes for a short course, organised by Bottjer, D. J., Hickman, C. S. and Ward, P. D. (Studies in Geology 13). University of Tennessee, Knoxville, pp. 88-101.

Seitz, O., 1962. Über Inoceramus (Platyceramus) mantelli Mercey (Barrois) aus dem Coniac und die Frage des Byssus-Ausschnittes bei OberkreideInoceramen. Geologisches Jahrbuch 79, 353-386.

Sowerby, J., 1814. Article XI. Annals of Philosophy, Linnean Society of London 4,448 .

Sowerby, J., 1822. On a fossil shell of a fibrous structure, the fragments of which occur abundantly in the chalk strata and in the flints accompanying it. The Transactions of the Linnean Society of London 13, 453-458, pl. 25.

Stanley, S.M., 1970. Relation of shell form to life habits of the Bivalvia (Mollusca). Geological Society of America Memoir 125, 1-296.

Stanley, S.M., 1972. Functional morphology and evolution of byssally attached bivalve mollusks. Journal of Paleontology 46, 165-212.

Stewart, J.D., 1990. Preliminary account of halecostome-inoceramid commensalism in the Upper Cretaceous of Kansas, in: Boucot, A. (Ed.), Evolutionary Paleobiology of Behaviour and Coevolution. Elsevier, Amsterdam, pp. 51-57.

Stow, D.A.V., Reading, H.G., Collinson, J.D., 1996. Deep seas, in: Reading, H.G. (Ed.), Sedimentary Environments: Processes, facies and stratigraphy. Blackwell science, Oxford, Third edition. pp. 395-453.

Tanabe, K., 1973. Evolution and mode of life of Inoceramus (Sphenoceramus) 
naumanni Yokoyama emend., an Upper Cretaceous bivalve. Transactions and Proceedings of the Palaeontological Society of Japan, New Series 20 , 163-184, pl. 27-28.

Tanabe, K., 1983. Mode of life of an inoceramid bivalve from the Lower Jurassic of west Japan. Neues Jahrbuch für Geologie und Paläontologie, Monatshefte 7, 419-428.

Tanoue, K., 2003. Larval ecology of Cretaceous inoceramid bivalves from northwestern Hokkaido, Japan. Paleontological Research 7, 105-110.

Tashiro, M., 1976. Bivalve faunas of the Cretaceous Himenoura Group in Kyushu. Palaeontological Society of Japan, Special Papers 19, 102, 12 pls.

Tashiro, M., 1978. On some interesting bivalves from the Cretaceous Himenoura Group in Kyushu. Transactions and Proceedings of the Palaeontological Society of Japan, New Series 110, 319-329.

Tashiro, M. (Ed.), 1992. Atlas of fossils (Cretaceous bivalves from Japan). Self-publishing, Kochi (in Japanese).

Tashiro, M., Noda, M., 1973. The geological age of the "Himenoura Group", Kyushu, Japan. Journal of the Geological Society of Japan 79, 465-480 (in Japanese, English abstract).

Tashiro, M., Taira, A., Matsumoto, T., 1980. Biostratigraphy and depositional facies of the Cretaceous-Tertiary boundary strata in Amakusa-Shimojima, Kyushu, western Japan. Cretaceous Research 1, 13-26.

Tashiro, M., Taniuchi, Y., Okamura, M., Yasuda, H., Maeda, H., 1986. Sedimentary environments of the lower part of Himenoura Group, AmakusaKamishima, Kumamoto Prefecture, southwest Japan. Research Reports of the Kochi University, Natural Science 35, 151-167, pl. 6 (in Japanese, English abstract).

Thayer, C.W., 1974. Marine paleoecology in the Upper Devonian of New York. Lethaia 7, 121-155.

Thayer, C.W., 1975. Morphologic adaptations of benthic invertebrates to soft substrata. Journal of Marine Research 33, 177-189.

Toshimitsu, S., 1988. Biostratigraphy of the Upper Cretaceous Santonian Stage in northwestern Hokkaido, Japan. Memoirs of the Faculty of Science, Kyushu University, Series D, Geology 26, 125-192.

Toshimitsu, S., Hasegawa, T., Tsuchiya, K., 2007. Coniacian-Santonian stratigraphy in Japan: a review. Cretaceous Research 28, 128-131.

Toshimitsu, S., Kano, M., Tashiro, M., 1992. Mode of occurrence and palaeoecology of a Cretaceous bivalve Sphenoceramus schmidti (Michael). Fossils (Journal of the Palaeontological Society of Japan) 52, 1-11 (in Japanese, English abstract).

Toshimitsu, S., Matsumoto, T., Noda, M., Nishida, T., Maiya, S., 1995. Towards an integrated mega-, micro- and magneto-stratigraphy of the Upper Cretaceous in Japan. Journal of the Geological Society of Japan 101, 19-29. (in Japanese, English abstract).

Toyohara, F., Matsuo, K., 2000. Mylonite in the Amakusa-Kamishima Island and the age of the formation. Kumamoto Journal of Science (Earth Sciences) 16, 29-34 (in Japanese, English abstract).

Ueda, Y., 1962. The type Himenoura Group. Memoirs of the Faculty of Science, Kyushu University, Series D, Geology 12, 129-178, pl. 22-27.

Ueda, Y., Furukawa, N., 1960. On the Himenoura Group of the AmakusaKamishima and adjacent islets, Kumamoto Prefecture. Science Reports of the Department of Geology, Kyushu University 5, 14-35 (in Japanese, English abstract).

Voigt, S., 1995. Palaeobiogeography of early Late Cretaceous inoceramids in the context of a new global palaeogeography. Cretaceous Research 16, 343356.

Walaszczyk, I., 2004. Inoceramids and inoceramid biostratigraphy of the Upper Campanian to basal Maastrichtian of the Middle Vistula River section, central Poland. Acta Geologica Polonica 54, 95-168.

Walaszczyk, I., Cobban, W.A., 2007. Inoceramid fauna and biostratigraphy of the upper middle Coniacian - lower middle Santonian of the Pueblo section (SE Colorado, US Western Interior). Cretaceous Research 28, 132-142.

Walker, R.G., Plint, A.G., 1992. Wave and storm-dominated shallow marine systems, in: Walker, R.G., James, N.P. (Eds.), Facies models: response to sea level change. Geological Association of Canada, Stittsville, Ontario, pp. 219-238.

Wallace, D.W.R., Wirick, C.D., 1992. Large air-gas fluxes associated with breaking waves. Nature 356, 694-696.

Ward, P.D., Kennedy, W.J., MacLeod, K.G., Mount, J.F., 1991. Ammonite and inoceramid bivalve extinction patterns in Cretaceous/Tertiary boundary sections of the Biscay region (southwestern France, northern Spain). Geology 19, 1181-1184.
Waterhouse, J.B., 1970. Permoceramus, a new inoceramid bivalve from the Permian of eastern Australia. New Zealand Journal of Geology and Geophysics $13,760-766$.

Wilmsen, M., 2008. An early Cenomanian (Late Cretaceous) maximum flooding bioevent in NW Europe: Correlation, sedimentology and biofacies. Palaeogeography, Palaeoclimatology, Palaeoecology 258, 317-333.

Woods, H., 1912. The evolution of Inoceramus in the Cretaceous Period. Quarterly Journal of the Geological Society of London 68, 1-20.

Yabe, H., 1900. Cretaceous Senonian strata in Amakusa area. Journal of the Geological Society of Japan 7, 277-278 (in Japanese).

Yabe, H., 1902. Note on three Upper Cretaceous ammonites from Japan, outside of Hokkaido (continued). Journal of the Geological Society of Japan 9, $1-7,1 \mathrm{pl}$.

Yamaguchi, H., Komatsu, T., Sato, M., Hasegawa, S., Nishi, H., 2008. Geology of the Upper Cretaceous Himenoura Group in the western part of Amakusa-Shimojima island, Kumamoto, Kyushu, Japan. Fossils (Journal of the Palaeontological Society of Japan) 84, 18-36 (in Japanese, English abstract).

Yazykova, E.A., 2002. Ammonite and inoceramid radiations after the Santonian. Campanian bioevent in Sakhalin, Far East Russia. Lethaia 35, 51-60.

Yehara, S., 1921. On the Izumi-sandstone in Kyushu. Journal of the Geological Society of Japan 28, 389-398.

Yehara, S., 1922. Cretaceous strata in Amakusa. Journal of the Geological Society of Japan 29, 138-148 (in Japanese).

Yehara, S., 1923. Cretaceous Trigoniae from Amakusa Islands, Prov. Higo, Kyushu, Japan. Journal of the Geological Society of Japan 30, 1-12, 1 pl. 


\section{Figure captions}

Fig. 1 Location of the study area (A) and distribution of the Upper Cretaceous Himenoura Group (in stripes) around the study area (B).

Fig. 2 Geologic map of the study area.

Fig. 3 Locality map of the study area.

Fig. 4 Generalized columnar section and invertebrate faunal succession of the lower part of the Hinoshima Formation, Himenoura Group in the study area. Stratigraphic distribution of modes of Inoceramus amakusensis occurrence (Types 1-3) is indicated. Depositional environments are based on Komatsu et al. (2008).

Fig. 5 Field photographs of sedimentary features and various modes of fossil occurrence. Hammer is $30 \mathrm{~cm}$ long. Lens cap is $5 \mathrm{~cm}$ and coin is $2 \mathrm{~cm}$ in diameter. A, trough and planar cross-stratified gravelly sandstones contain rounded granules to boulders (Loc. K2003). B, shell fragments of Inoceramus amakusensis (arrowed) embedded in the gravelly trough cross-stratified sandstone (Type 3); structure of prismatic layer is observed at the fracture surface of each (Loc. K2004); photograph shows cross-section. C, low-angle to hummocky cross-stratified (HCS) sandstone (Loc. H4002). D, HCS sandstone (Loc. K2006). E, disarticulated large valves of I. amakusensis (Type 2) accumulate in a bedding plane of HCS sandstone bed (Loc. K2006). F, cross-section of intensely bioturbated sandstone beds (Loc. K2006). G, cross-section through autochthonous individuals of Glycymeris amakusensis (arrowed); bedding plane view of bioturbated sandstone (Loc. H4002). H, well-preserved left valve of I. amakusensis (Type 2); note that the posterior wing (PW) is visible (Loc. K2008); bedding plane view of bioturbated sandy mudstone.

Fig. 6 Inoceramus amakusensis Nagao et Matsumoto, 1940 (left valve, internal cast) from HCS sandstone of the Hinoshima Formation at Loc. K2006; note that umbo, posterior wing, and faint concentric lines are preserved (Type 2).

Fig. 7 Schematic columnar section of HCS and bioturbated sandstones in which in situ Inoceramus amakusensis (Type 1) and autochthonous Glycymeris amakusensis are embedded (Loc. H4002); pie chart represents articulate-disarticulate ratio of $I$. amakusensis, and rose diagram shows the frequency of the angle formed between commissural plane and bedding plane.

Fig. 8 Field photograph (A) and schematic sketch (B) of cross-section through Inoceramus amakusensis in life position (Type 1) embedded perpendicularly in fine-grained bioturbated sandstone at Loc. H4002; note that the posterior part is crushed.

Fig. 9 Life position and cross-sectional shape of Inoceramus amakusensis based on the specimens illustrated in Figs. 6 and 8 (lateral view, left valve); fragmentary specimen (left) corresponds to shaded area on the sketch of I. amakusensis (right) modified after Tashiro (1992); gray fish indicates the observation direction in Fig. 8; open arrows indicate the position of cross-section (right); striped area in the cross-section denotes maximum shell-width. 


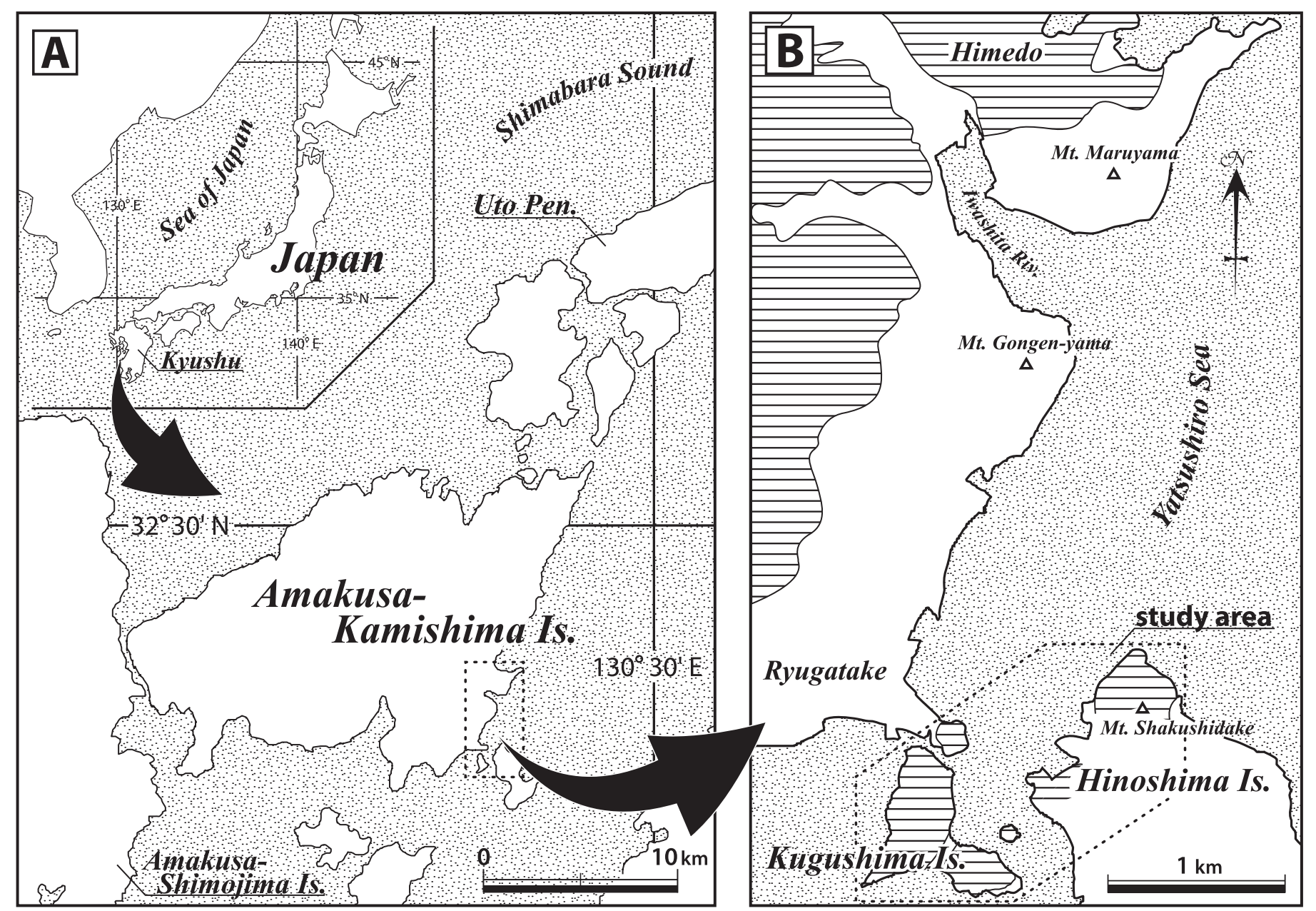

Figure 1. 

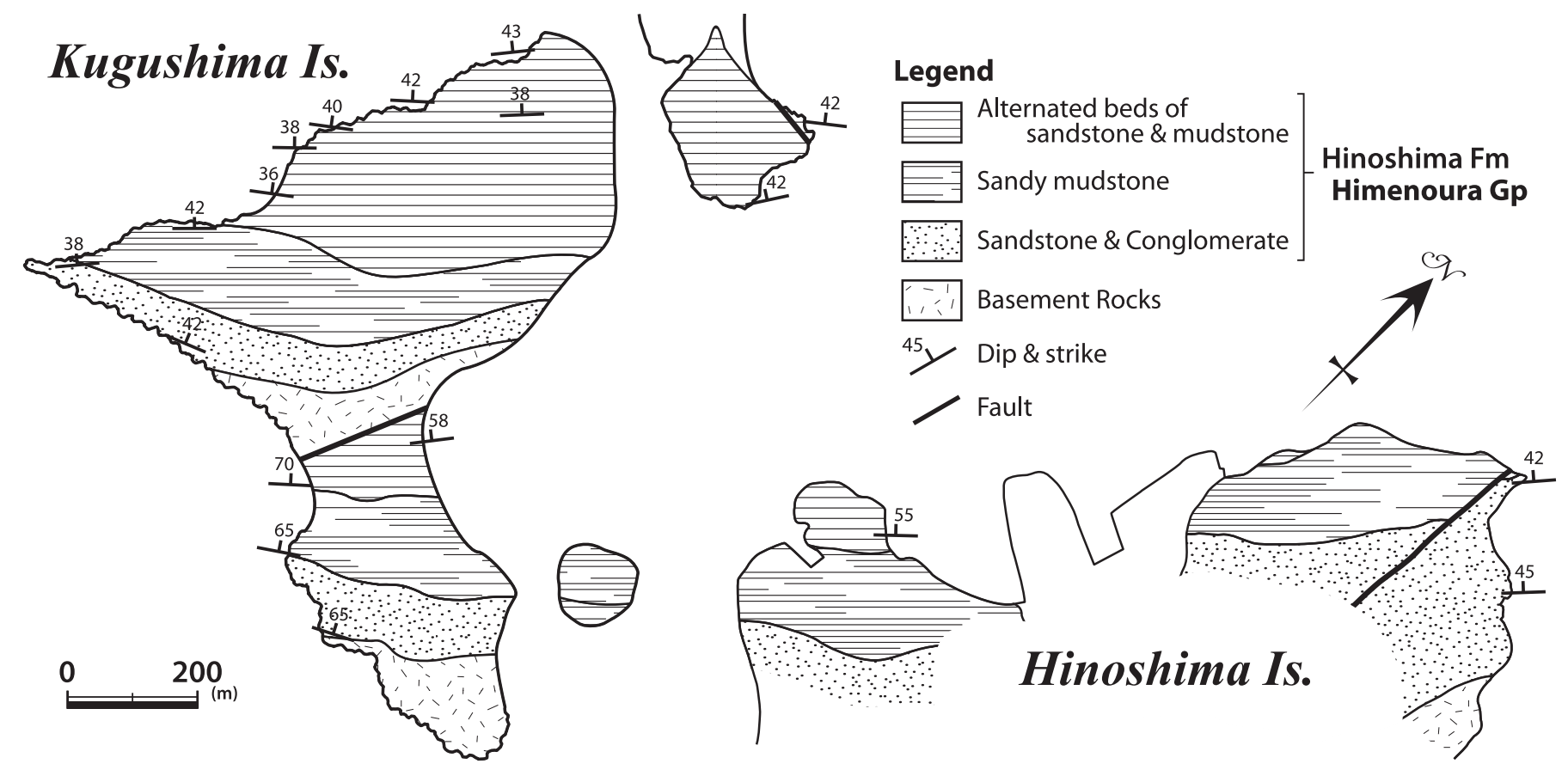

Figure 2. 


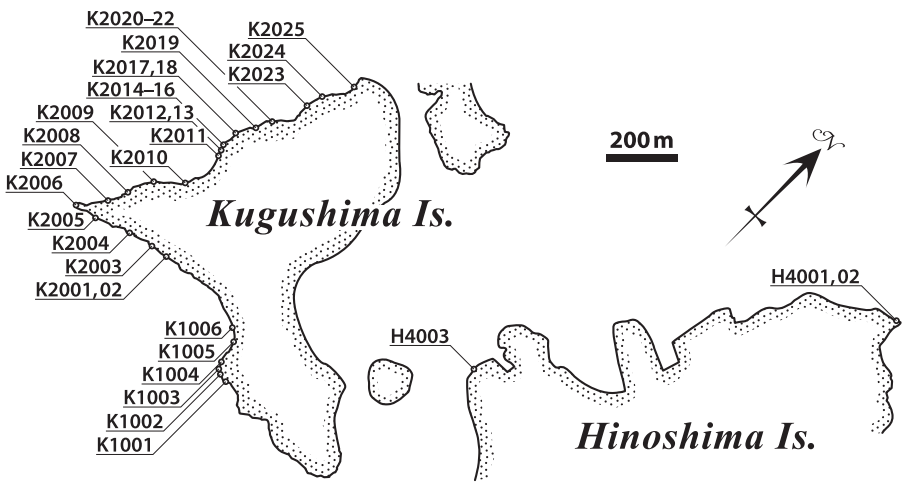

Figure 3. 


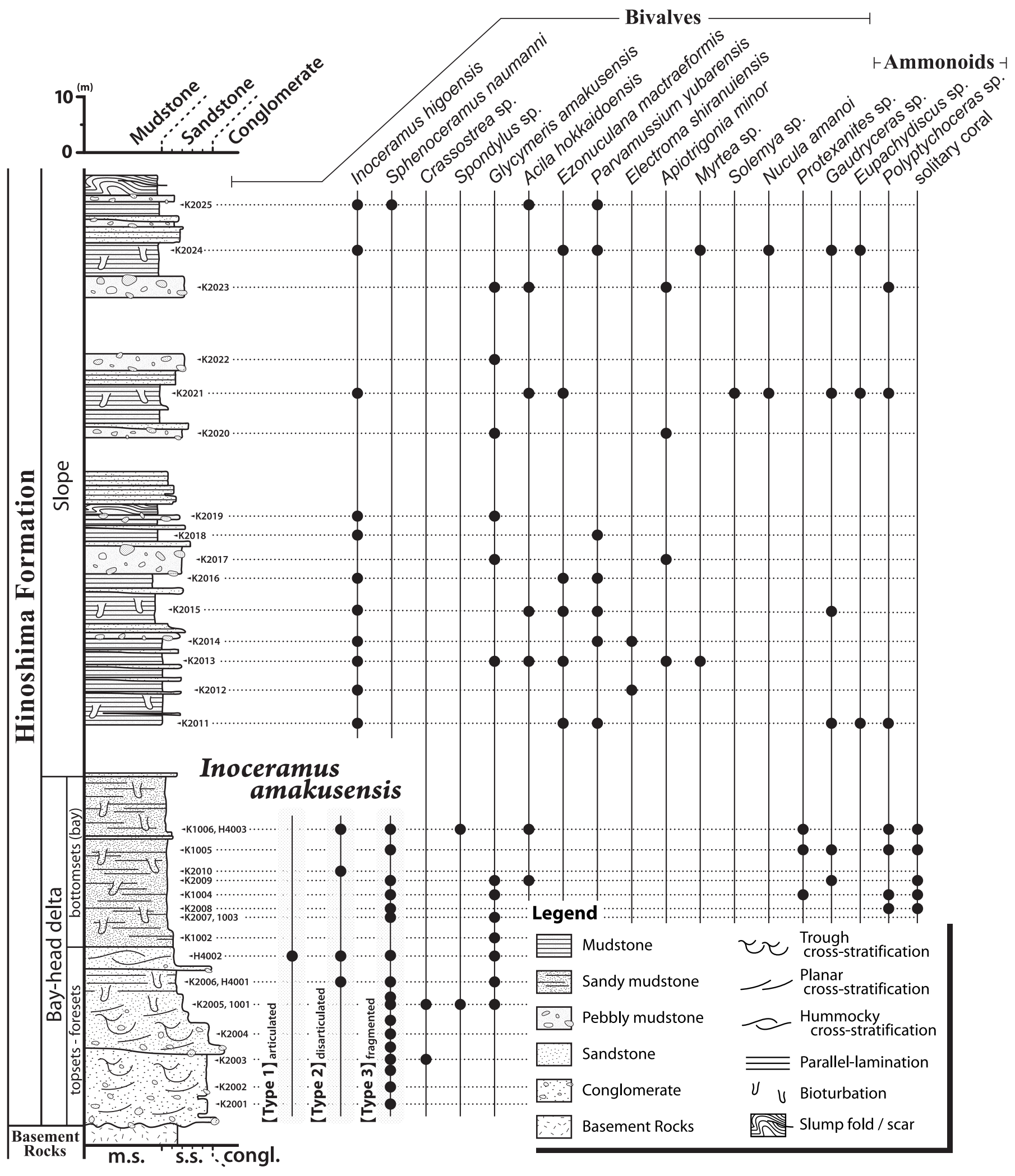

Figure 4. 

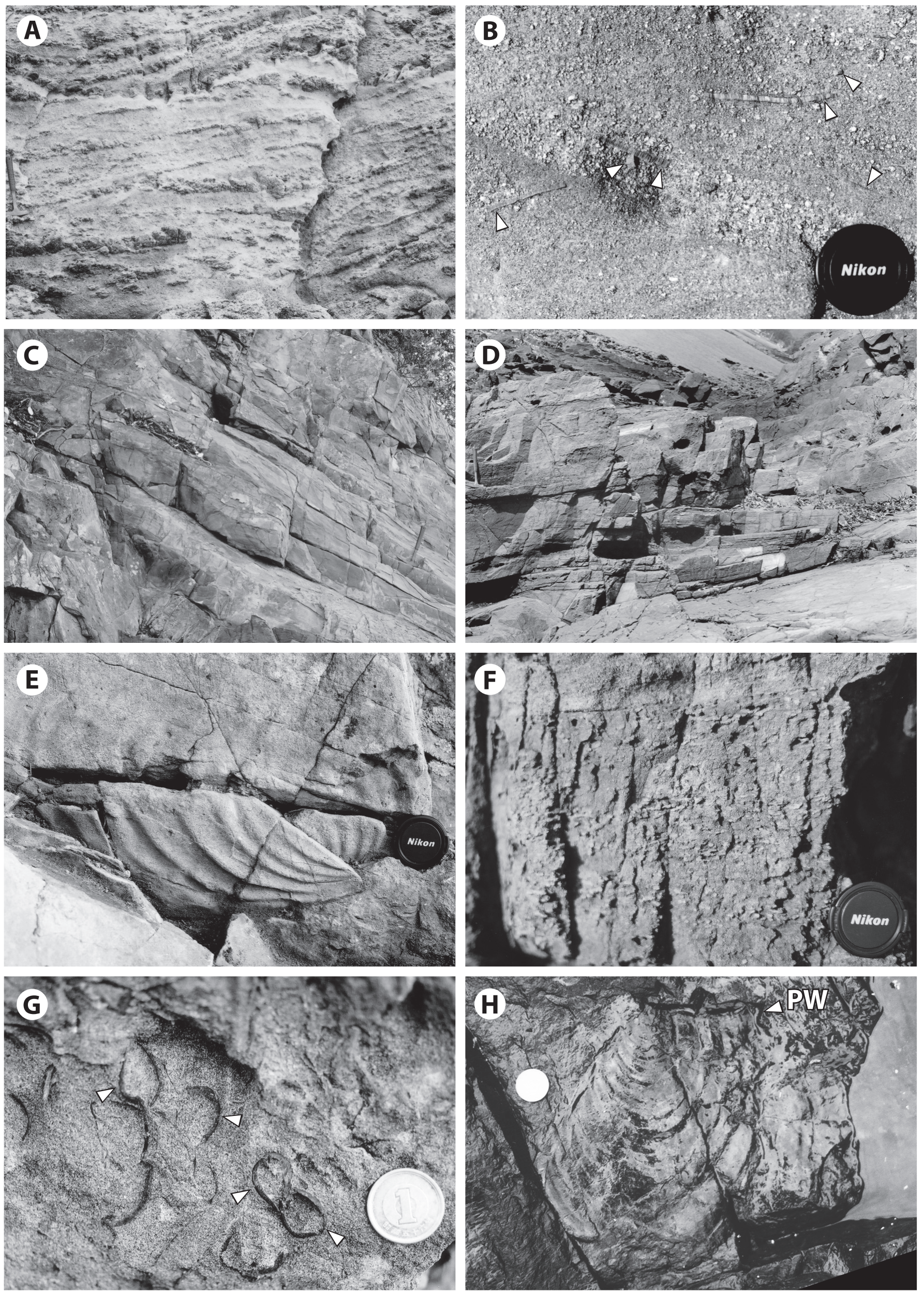


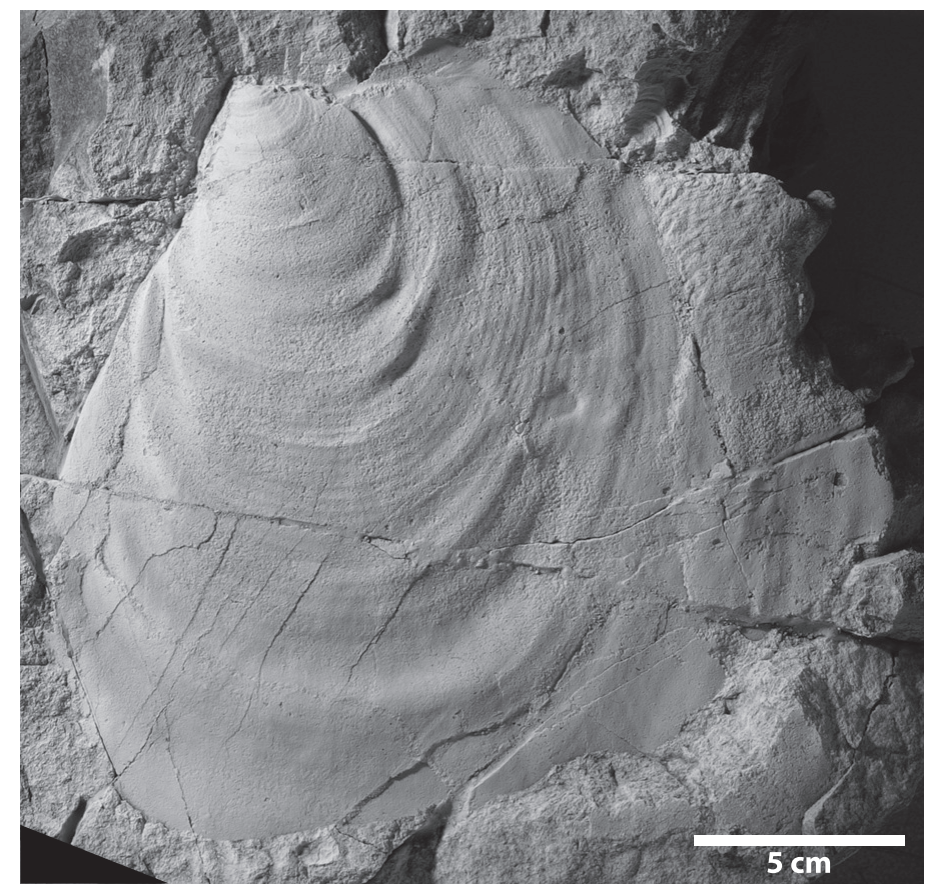

Figure 6. 


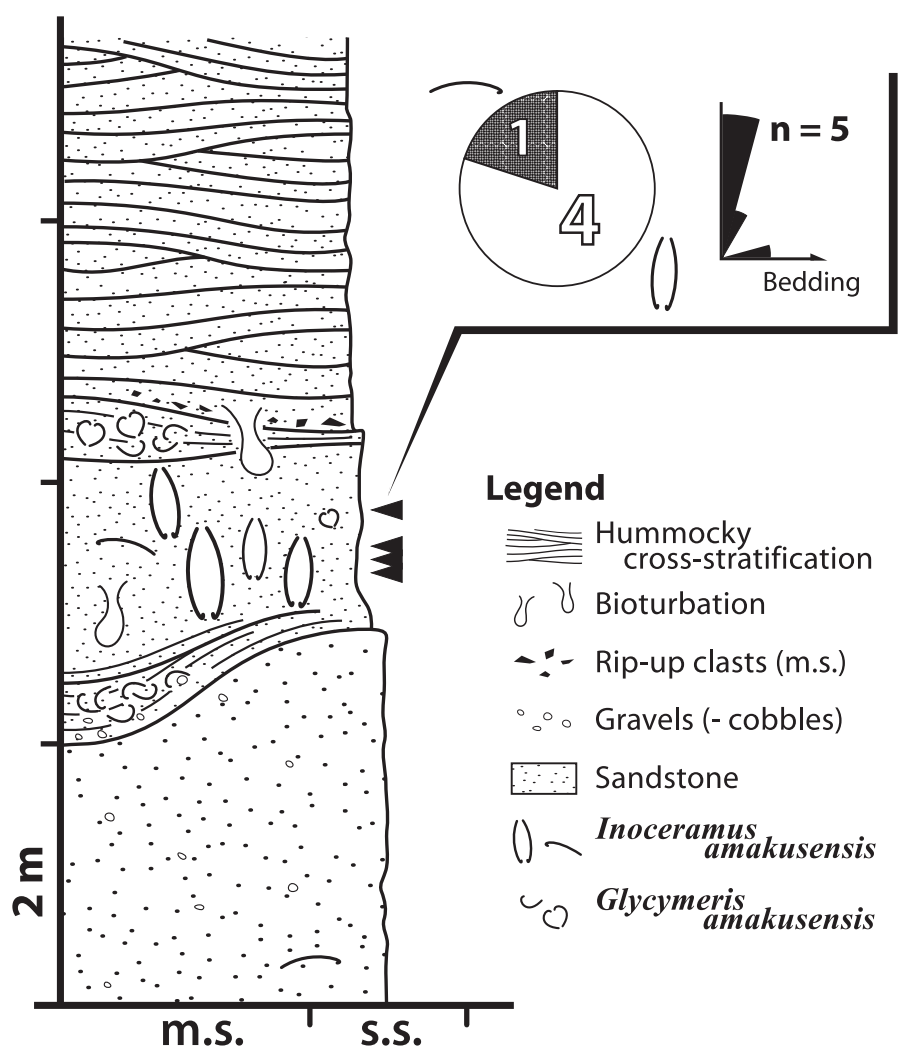

Figure 7. 


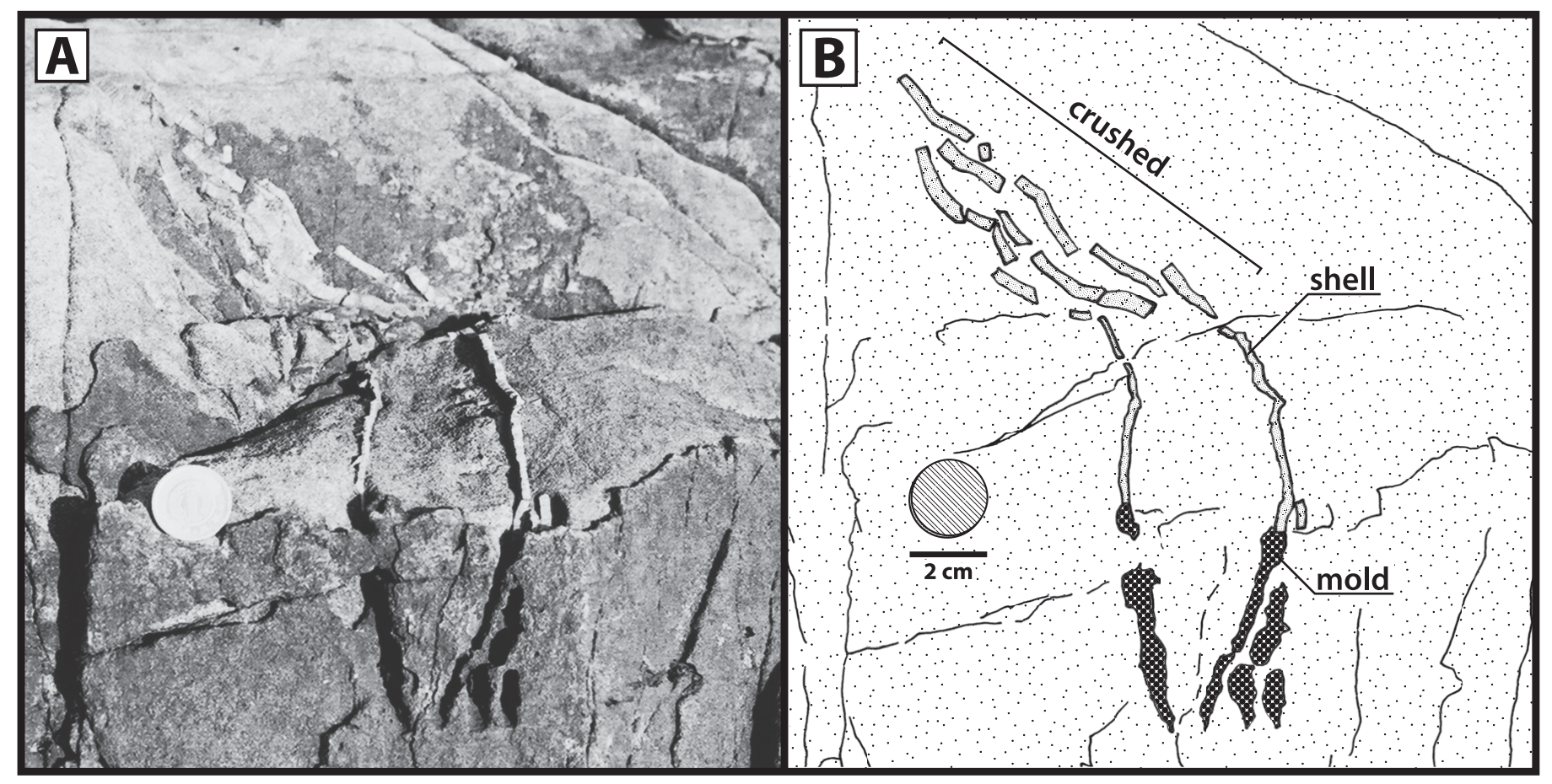

Figure 8. 


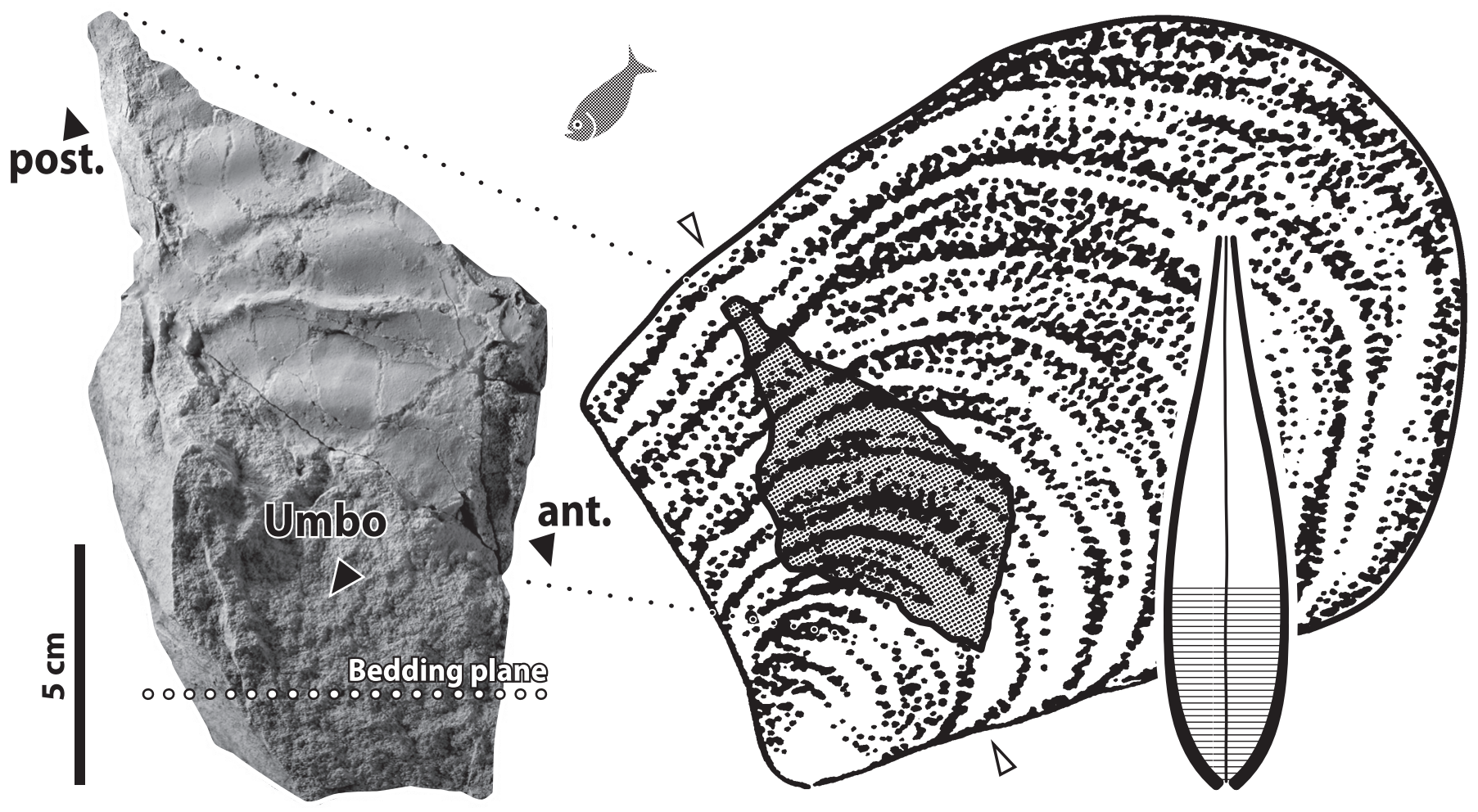

Figure 9. 


\section{Highlights}

$>$ The first record of a Santonian inoceramid, Inoceramus amakusensis in upright life position.

$>$ This species inhabited storm- and wave-influenced, well-oxygenated sandy bottoms during mid-ontogeny.

$>$ Its life position is comparable to that of endobyssate mytilids or semi-infaunal sand stickers.

> I. amakusensis, possibly by changing its life habit, could have adapted to various marine environments. 